\title{
Creating a Culture of Engagement -- Insights for Application
}

\author{
Sarah Sanders Smith ${ }^{1}$, Ray Peters ${ }^{2} \&$ Cam Caldwell $^{3}$ \\ ${ }^{1}$ Purdue University Northwest, Westville, IN, USA \\ ${ }^{2}$ RoyOMartin, Alexandria, LA, USA \\ ${ }^{3}$ Dixie State University, St. George, UT, USA \\ Correspondence: Sarah Sanders Smith, College of Business, Purdue University Northwest, Westville, IN, 46391, \\ USA. Tel: 1-219-785-5684
}

Received: May 20, 2016

Accepted: June 7, 2016

Online Published: June 14, 2016

doi:10.5430/bmr.v5n2p70

URL: http://dx.doi.org/10.5430/bmr.v5n2p70

\begin{abstract}
Harvard's Clayton M. Christensen $(2012,2013,2016)$ has repeatedly emphasized the critical importance of engaging employees at all organizational levels to achieve and sustain competitive advantage in today's fast moving global marketplace. At the same time, other scholars have noted that many leaders and organizations are ineffective (Pfeffer, 1998) and Angela Duckworth (2016) has reported that two-thirds of today's employees describe themselves as not engaged in their organization. The challenge of creating a culture of engagement and commitment has increasingly been addressed by scholars and practitioners and acknowledged to be critical to the success of the modern organization (Hayes, Caldwell, Licona \& Meyer, 2015; Caldwell, Licona, \& Floyd, 2015; Schein, 2010).

The purpose of this paper is to identify the critical importance of creating a culture of engagement and to clarify key roles of the top management team, the human resources staff, individual supervisors, and non-supervisory colleagues in creating that culture. We begin this paper by briefly defining employee engagement and explaining its important place in organizations that seek to improve quality, profitability, and innovation. We then identify the important roles of key individuals and groups in creating a culture of engagement and offer six propositions to test related to increasing employee commitment and creating a culture of high engagement. We conclude with a brief summary of the contributions of this paper.
\end{abstract}

Keywords: Employee engagement, Culture, Psychological contracts, Trust, Communication

\section{Understanding Engagement}

Macey and Schneider (2008, p. 3) defined employee engagement as referring "to psychological states, traits, and behaviors as well as their antecedents and outcomes." Saks (2006, p. 602) similarly defined employee engagement as "a distinct and unique construct consisting of cognitive, emotional, and behavioral components . . associated with individual role performance." Shuck (2010) explained that employee engagement consists of long-term emotional involvement and is an antecedent to job satisfaction and commitment (cf. Wagner \& Harter, 2006). Engaged employees have a high level of enthusiasm for their work (Buckingham, \& Coffman, 1999), and consistently produce at higher levels than unengaged employees (Meere, 2005).

Surprisingly, however, only about one in three employees self-describes as being "engaged" and the modern organization is notoriously ineffective at creating a culture of high trust, high performance, and high engagement (cf. Schein, 2010). The Gallop organization has measured self-reported levels of employee engagement since 2000. The 2014 survey included 80,837 randomly selected adults and found employee engagement had risen somewhat, but only to $31.5 \%$ (Adkins, 2015). According to Adkins (2015) the majority of employees (51\%) were "not engaged" and $17.5 \%$ were "actively disengaged". Ketter (2008) showed that organizations with highly engaged employees were more profitable than those organizations with fewer engaged employees. Rath and Clifton (2004) estimated that the cost of unengaged employees in the United States was $\$ 250$ to $\$ 300$ billion per year - potentially rising to $\$ 1$ trillion per year when other related costs such as turnover, absenteeism, fraud, and workplace illness are factored into the equation.

In contrast, research about high performance and high trust work systems has shown that highly committed employees resulting from organizations that engage employees by creating such systems are financially more successful, produce more innovation, provide better customer service, and are more likely to be sustainable 
long-term than other organizations (Pfeffer, 1998; Luthans, Youssef, \& Avolio, 2007; Pfeffer \& Sutton, 2013). According to Lockwood (2007), employee engagement is key to customer satisfaction, company reputation and overall stakeholder value. Davenport (2013) is just one of many scholars who has explained that today's knowledge workers must be engaged and committed employees, deploring "traditional" top-down high control management systems that characterized the industrial age - but that are still practiced in many organizations. In times of organizational change within a global marketplace, organizations must embrace the understanding that enhancing employee engagement can result from a direct relationship between the employee and his/her immediate supervisor. As frequently stated, people leave managers, not companies (Lipman, 2015).

Clearly, the importance of highly committed and engaged employees is in every organization's interest - yet it is the unusual organization that successfully creates an organizational culture of high trust, high performance, and high employee commitment (Federman, 2009; Burchell \& Robin, 2011). Although scholars like Harvard's Lynn Paine (2003) have documented the need to merge social and financial imperatives to create better organizations, many organizations and their leaders continue to be focused on downsizing, reducing their commitment to employees' welfare, and focusing on short-term profits in their pursuit of organizational success (Covey, 2004; Brown, 2005; Perrini, Russo, Tencati, \& Vurro, 2011).

\section{Creating a Culture of Engagement}

Organizations that successfully create a culture of engagement recognize that doing so requires aligned programs, practices, policies, and systems (Pfeffer, 1998; Caldwell, Licona, \& Floyd, 2015). Weinzimmer, Robin, and Michel (2012, p. 81) have defined organizational culture as "a complex set of shared values, beliefs, philosophies, and symbols that define the way in which a firm conducts its business." Robbins (2001) confirmed that organizational culture defines appropriate boundaries and performance standards. Huhtala and colleagues (2015) explained that an organization's culture articulated its values - and especially its ethical expectations for organization members.

The relationship between employee engagement and creating a culture of engagement is understood in terms of the nature of engagement's key dimensions. Schaufeli and Bakker (2010) explain that the cultural beliefs of employees support the goals and values of the organization. At the emotional or affective level, the culture of engagement also creates pride, a sense of belonging, and affiliative attachment to the organization. At the behavioral level, those beliefs and attitudes are then translated into organizational citizenship behavior or the willingness to go the extra mile in the pursuit of organizational objectives.

Manion (2012) has defined a culture of engagement in terms of the ongoing need for organizations to manage change. Teneja and colleagues (2015) identified a culture of employee engagement as a key to strategic success for the modern organization and defined that culture as reflecting a two-way long-term commitment between employees and their organization. In addition, Tenja and colleagues (2015) enumerated the importance of creating a culture of engagement in retaining an organization's best employees.

Freeman (2010) reported that studies about employee engagement indicate that only from $11 \%$ to $29 \%$ of employees describe themselves as fully engaged. But Rothwell (2014) also noted that creating a culture of engagement was directly related to increased employee ownership and commitment; reduced turnover and health and safety problems; and improved productivity, profitability, and customer satisfaction. In 2012, Gallop conducted a meta-analysis which included 192 organizations within 49 industries. The study spanned 34 countries. Gallop researchers statistically identified relationships between employee engagement and nine organization performance measures: quality (defects), customer ratings, profitability, productivity, turnover, safety incidents, absenteeism, shrinkage (theft), and patient safety (Sorenson, 2013).

\section{Increasing Employee Engagement}

In this section of the paper we address key elements associated with creating a culture of employee engagement, identify the key roles of organizational members in enhancing engagement, and offer six propositions about increasing employee commitment, motivation, ownership, and extra-mile behaviors.

\section{Engagement and a Culture of Trust}

High trust or high performance work systems focus on treating employees as valued owners and partners (Block \& Piersanti, 2013) and empower employees by decentralizing responsibility for decision-making, creating self-managed teams, learning organizations, sharing key information, reducing status barriers, and creating aligned human resource management systems that value employees and treat them with dignity and respect (Caldwell \& Floyd, 2014; Kivland, 2016; Pangarkar, 2011; Loehr \& Schwartz, 2005). For organizations, trusting employees equates to giving them the power to innovate, take personal initiative, be creative, and make decisions within 
value-based parameters without being micromanaged (Pfeffer, 1998; Pfeffer \& Sutton, 2013). Organizations whose values include trusting employees, empowering them to become their best, and assisting them to develop skills that benefit themselves and the organization demonstrate that they are committed to both the transformational goals of the organization and the welfare of their employees (Covey, 2004). In a study of leading CEOs in Chicago, trust; specifically the ability to convey to someone that the manager was confident in the employee's ability to meet work expectations and goals, was identified as one of the most important attributes for effective leadership (Cherniss, Grimm, \& Liautaud, 2010).

Similar to trust (Brower, Schoorman, \& Tan, 2000), engagement and employee commitment are measured on a continuum (cf. Senge, 2006). Table One explains that continuum of employee buy-in to organizational goals and values, from passive-aggressive obedience to employee stewardship.

Table 1. The Compliance - Commitment Continuum of Employee Engagement

\begin{tabular}{|c|c|c|c|}
\hline Employee Response & Brief Description & Engagement Level & Organization Impact \\
\hline $\begin{array}{l}\text { Passive-Aggressive } \\
\text { Compliance }\end{array}$ & $\begin{array}{l}\text { Employees comply strictly with } \\
\text { rules and regulations, knowing } \\
\text { that doing so actually impedes } \\
\text { goal achievement. }\end{array}$ & $\begin{array}{l}\text { Engagement is actually } \\
\text { negative and is intended to } \\
\text { withhold trust and } \\
\text { commitment. }\end{array}$ & $\begin{array}{l}\text { The organization suffers } \\
\text { due to employee efforts } \\
\text { that are often retaliatory } \\
\text { toward management. }\end{array}$ \\
\hline $\begin{array}{l}\text { Reluctant } \\
\text { Indifference }\end{array}$ & $\begin{array}{l}\text { Employees accept management } \\
\text { or organizational requirements } \\
\text { but may do so with minimally } \\
\text { acceptable effort and } \\
\text { commitment. }\end{array}$ & $\begin{array}{l}\text { Trust is often conditional } \\
\text { and employee engagement } \\
\text { may focus on doing } \\
\text { enough to avoid being } \\
\text { terminated in order to } \\
\text { retain employment. }\end{array}$ & $\begin{array}{l}\text { The employee } \\
\text { participation is motivated } \\
\text { by self-interest and may be } \\
\text { based upon a standard of } \\
\text { minimum compliance and } \\
\text { contribution. }\end{array}$ \\
\hline $\begin{array}{l}\text { Transactional } \\
\text { Acceptance }\end{array}$ & $\begin{array}{l}\text { Employee performance is } \\
\text { typically based upon a quid pro } \\
\text { quo exchange of work for } \\
\text { incentives. }\end{array}$ & $\begin{array}{l}\text { Distrust may be present to } \\
\text { some degree but the } \\
\text { expectation is that the } \\
\text { exchange relationship } \\
\text { obligates both parties. }\end{array}$ & $\begin{array}{l}\text { Employee engagement and } \\
\text { participation is essentially } \\
\text { purchased by the employer } \\
\text { in exchange for } \\
\text { compensation and } \\
\text { benefits. }\end{array}$ \\
\hline Willing Participation & $\begin{array}{l}\text { Employees demonstrate a } \\
\text { commitment to the } \\
\text { organization's goals and values. }\end{array}$ & $\begin{array}{l}\text { Engagement is moderate } \\
\text { and reflects occasionally } \\
\text { high levels of performance } \\
\text { and generalized trust. }\end{array}$ & $\begin{array}{l}\text { Contributions are made to } \\
\text { organizational goals and } \\
\text { the organization benefits } \\
\text { from employee efforts. }\end{array}$ \\
\hline Engaged Cooperation & $\begin{array}{l}\text { Employees demonstrate } \\
\text { generally high compliance with } \\
\text { organizational polices and } \\
\text { endorse articulated values. }\end{array}$ & $\begin{array}{l}\text { Engagement is generally } \\
\text { very good and } \\
\text { occasionally outstanding. } \\
\text { Trust in leaders is also } \\
\text { generally very good. }\end{array}$ & $\begin{array}{l}\text { Cooperation leads to } \\
\text { organizational goal } \\
\text { achievement, progress, and } \\
\text { improvement. Wealth is } \\
\text { created and value is added. }\end{array}$ \\
\hline $\begin{array}{l}\text { Employee } \\
\text { Stewardship }\end{array}$ & $\begin{array}{l}\text { Employees act as if they are } \\
\text { true "owners and partners" } \\
\text { committed to the organization's } \\
\text { best interests. }\end{array}$ & $\begin{array}{l}\text { Engagement and employee } \\
\text { commitment are at its peak } \\
\text { and employees willingly } \\
\text { go the extra mile. }\end{array}$ & $\begin{array}{l}\text { Wealth creation and value } \\
\text { added is at its highest } \\
\text { level. Creativity, } \\
\text { innovation, and continuous } \\
\text { improvement are achieved. }\end{array}$ \\
\hline
\end{tabular}

Follower commitment enhances the ability of organizations to create wealth and compete successfully, but that commitment is tied to employee perceptions about the trustworthiness of those who lead them (Hayes, et al., 2015) and the culture that those leaders create (Schein, 2010). Peshawaria (2013) makes the logic simple: If employees trust their organizational leaders, then those employees will give $110 \%$ to their work.

Schein (2010) has clearly articulated the important role that an organizational leader plays in creating an organizational culture, articulating and defining its values, and ensuring that organizational systems are in place to operationalize that culture. The perceived trustworthiness of leaders is based upon the degree to which their behaviors and actions are consistent with the organization's articulated culture, its espoused values, and the alignment of human resource policies and procedures with those values (Pfeffer, 1998; Covey, 2004; Hosmer, 2010). Consistent with the relationship between the levels of employee engagement and the culture within an organization, we present our first proposition. 
$P_{1}$ : Organizations with leaders who create a high trust employee culture with aligned values, policies, and practices will also have employees who demonstrate higher levels of engagement than organizations without those culture elements.

\section{Engagement and Psychological Contracts}

The degree to which commitments between individuals or between an individual and an organization are perceived to be honored is often a subjective perception that is based upon each party's interpretation of the psychological contract that exists (Rousseau, 1995). Psychological contracts between employees and supervisors are typically individually perceived but rarely mutually understood in the same terms by the two parties (Robinson \& Rousseau, 1994). Psychological contracts are generally associated with social exchange theory and involve reciprocal mutual obligations, typically creating a "balanced exchange" which is usually perceived to be ethical and just when the contract is mutually understood (Johnson \& Oleary-Kelly, 2003). However, Kickul (2001) noted that employee expectations associated with psychological contracts were broad and often resulted in the perception that the non-fulfillment of their expectations created a breach wherein 1) a desired outcome did not result, 2) perceived procedures were not followed, or 3) treatment by the supervisor was perceived as unfair.

Thompson and Hart (2006) explained that psychological contracts have their roots in moral and ethical assumptions of the parties to a social contract. A breach of expected outcomes can impact employee loyalty and commitment and reduce levels of engagement or extra role behavior (Hart \& Thompson, 2007). Supervisors can reduce employee perceptions of psychological contract breach by 1) clarifying and carefully following organization policies and rules, 2) establishing relationships with individual employees in which supervisors have a clear understanding of employee perceptions, 3) listening carefully and asking employees what they expect of the organization in performance coaching and evaluation meetings, and 4) going the extra mile to honor promises made and demonstrate their commitment to employees' welfare, growth, and wholeness (Covey, 2004). Organ, Podsakoff, and MacKenzie (2005) have noted that employees prone to organizational citizenship or extra role behavior reflecting high engagement were much more likely to exhibit those behaviors when supervisors were perceived as ethical. The fulcrum for effectively leveraging and sustaining psychological contacts with employees is directly correlated to the actions of their immediate leader. An article released by the Corporate Leadership Council (2004), highlighted the following characteristics of leaders that promote employee engagement: 1) show strong commitment to diversity; 2) take responsibilities for successes and failures; 3) demonstrate honesty and integrity; 4) help find solutions to problems; 5) respect and care for employees as individuals; 6) set realistic performance expectations; 7) demonstrate a passion for success; and 8) defend direct reports.

While top organizational leaders may desire to establish a culture of employee engagement, translating that vision through all levels of leadership is often not given the Human Resource Development attention necessary to fully facilitate the desired transition. Without the commitment and reinforcement of first-level leadership, any attempt at increasing a more highly engaged workforce may prove problematic.

Consistent with this research about psychological contracts, we offer our second proposition.

$P_{2}$ : Organizations with supervisors who understand the nature of psychological contracts and who play close attention to understanding employee perceptions and honoring commitments are much more likely to have their employees respond with higher levels of engagement and commitment.

\section{Engagement and Aligned Human Resources}

The strategic integration of human resource management systems creates organizational cultures that communicate a powerful message to organization members about the competence and integrity of their organization and the quality of those human resource systems (Ulrich \& Younger, 2012). In creating organizations that successfully create high trust, creative and innovative cultures, and profitable performance, Pfeffer and Sutton (1998) identified the importance of aligned human resource management systems that consistently integrate human resource management systems with company values. Human resource managers can foster an environment for engagement by developing a targeted, proactive strategic communication plan (Lockwood, 2007). Clear, consistent and honest communication is an important management tool for employee engagement.

It is well documented in the management literature that aligned human resource management policies and systems create greater impact on employee commitment and organization performance than organizations with human resource management systems that are only partially aligned in their systems and values (Hollenbeck \& Jamieson, 2015). Manroop and colleagues (2014) offered evidence that integrated human resource systems and practices are also perceived as more ethical than unaligned systems and practices. Akinlade and Shallack (2016) suggest that the 
systems and practices of human resource management should be both strategic and mission driven to be most effective and to be perceived as values-based. In keeping with this information about the alignment of human resources with company values, we present our third proposition.

$P_{3}$ : Organizations with human resource departments that integrate and align human resource management systems and practices with company values have employees who are more engaged and likely to participate in extra role behaviors than organizations that do not have human resource departments with systems and practices that are integrated and aligned.

\section{Engagement and Beneficence}

Creating a culture that encourages high commitment, willingness to risk, the drive to constantly improve products and systems, and the curiosity to create new knowledge is best achieved when leaders model behaviors that demonstrate that they value employees as "yous" rather than as "its" (cf. Buber \& Smith, 2011). Beneficence is the interpersonal treatment of one person by another that demonstrates a commitment to the welfare, growth, wholeness, and best interests of that other party (Caldwell, et al., 2014). Whereas benevolence is an attitude, beneficence encompasses the behaviors and actions that one individual takes in treating others with kindness, respect, and an authentic concern for their best interests (Beauchamp, 2008). Beneficence in actions demonstrates the trustworthiness of one party to another and is a fundamental characteristic of transformational leadership (Burns, 2010).

Kouzes and Posner (2012) noted that the most effective leaders in their extensive research treat others with a commitment to their best interests and "encourage the heart." Bennis and Nanus (2007) similarly noted that today's organizations demand a "transformative" approach to creating relationships with employees by creating an open and empowered culture that values the individual and seeks their best interests - as well as the best interests of the organization. Schein (2010) placed the responsibility for creating a great organization culture on the organization's top management team, emphasizing that their ability to build culture required that the leaders model the values that they advertise in honoring relationships and empowering employees. Block and Piersant (2013) also noted that leadership was a special stewardship in which employees were treated as valued owners and partners, rather than simply as hired help. DePree (2004) declared this obligation to pursue the best interests of employees as a "covenantal duty" and a sacred obligation of organizations and leader - noting that by honoring duties owed to employees they will then reciprocate by becoming valued contributors to the organization's success. Having this "employee orientation" (Bowers \& Seashore, 1966), involves taking an interest in workers as human beings, valuing their uniqueness and giving special attention to their personal needs. Northouse (2015), puts it this way: Relationship leadership is about three things: 1) treating followers with dignity and respect; 2) building relationships and helping people get along and 3) making the work setting a pleasant place to be.

Consistent with this discussion of beneficence and its impact on employee engagement, we present our fourth proposition.

$P_{4}$ : Organizations with top management teams that demonstrate authentic concern for employees' interests and treat them with beneficence are more likely to have highly committed and engaged employees than organizations that do not demonstrate concern and beneficence.

\section{Engagement and Coaching - Front Line Managers}

Managers are important when coaching employees (Ellinger, 2012). A direct supervisor has the most access to his or her employees and thus has the opportunity to listen, observe, and to monitor for levels of work stress or overload. Great managers consistently motivate their teams to achieve outstanding performance (Atkins, 2015) and thus, front-line supervisors have the opportunity to coach employees in order to encourage direct reports to do their best and deliver outstanding performance. Coaching from the front-line manager who functions as an organizational leader has been evidenced as a preferred method which has produced positive results (Kilroy \& Dundon, 2015).

According to Ashkenas, Ulrich, Jick, \& Kerr (2015), the contemporary boundaryless organization trains all employees and offers strategic education to various levels of employees and supervisors. Regular training helps elevate employees' concerns when working in a dynamic, global market as well as during times of organizational change. Increased training has resulted in a greater desire for promotion from within (DeVaro \& Morita, 2013). In contrast to proposing higher levels of external recruitment (when new employees and supervisors dedicate time to learn the annual business cycle and understand the organization's culture), companies that dedicate to training new and existing employees develop new supervisors within the organization and experience higher productivity and lower costs of turnover (Colombo \& Stanca, 2014; Ashar, Ghafoor, Munir, \& Hafeez, 2013). 
However, developing today's supervisors as coaches within the non-hierarchical organization presents a challenge (Burke \& Noumair, 2015). In manufacturing, time away from production is often minimized in order to support productivity goals for the company through daily production schedules. In addition to being asked to be organizational leaders and coaches, today's managers must be open and approachable to the people they lead (R. Peters, personal communication, May 16, 2016). This is a significant shift in the front-line supervisors' leadership expectations and thus, it is unrealistic and perhaps unfair to expect that previously successful front-line managers will be able to migrate quickly to new methods of leadership, including coaching. Even when development opportunities are made known and are clearly communicated, the best organizational development efforts can lack transfer of training over time as front line managers revert to their old ways (Robbins, De Cenzo, Coulter, \& Woods, 2013).

Lack of training and development effectiveness has been acknowledged by the Association for Talent Development. Of $\$ 164.2$ billion dollars spent on learning and development programs annually in the United States, only 20 percent of dollars invested resulted in permanent transfer of training or positive impact to organizations' profits (ASTD Research, 2013). Kivland and King (2014) identified six reasons leadership training fails:

1) Companies fail to require measures of the permanency for leadership training. "If you can't measure it, you can't improve it" - Peter Drucker. 2) Lack of manager's support. The immediate supervisor does not ensure time for training and practice to integrate what is learned for the learner, or, rewards systems do not support development of new skills. 3) Top leaders do not walk the talk. When leadership training and development focuses only mid-management and frontline employees, the critical component authentic leadership support is missing. 4) Low levels of training evaluation are used. Most organizations rely on Level 1 Kirkpatrick evaluation which does not provide evaluation of transfer of training and more important, on-the-job behavior or skill shifts. 5) Absence of audit and feedback. Level 3 Kirkpatrick evaluation looks at long-term transfer of training. When initiating leadership development programs (including coaching) observation and feedback over time are needed. 6) An absence of pre-screening to determine the leadership trainee's compatibility to the training and its culture to the training and its culture. This acknowledges the challenge of busy production schedules as well as factors such as the trainee's willingness, motivation, and attitude toward leadership development.

To develop capable coaches, the organization must provide time for training as well as opportunities to incorporate new coaching skills. Top leadership support by walking the talk illustrates the importance of leadership development within the organization. A comprehensive measurement and evaluation process ensures progress for those learning new or improved coaching skills as well as offers tangible evidence of training effectiveness to the organization's leaders. Consistent with research regarding engagement, coaching and front-line managers, we present our fifth proposition.

$P_{5}$ : Front line managers who are supported by their organization while learning leadership skills to develop coaching techniques will in turn develop more engaged employees than organizations that do not support front-line managers' leadership development.

\section{Engagement and a Sense of Belonging}

Adkins (2015) identified that the least engaged employees were the millennial generation. Since the millennial population represents a significant hiring pool for today's organizations, concerns about millennials' impressions of self-belonging are critical to consider. The sense of self-belonging is created through the development of trust between organizational leaders and employees (Kirkland, 2016). The foundations of this relationship have often been overlooked by traditional leadership training programs (Kivland \& King, 2015)

Organizations create relationships with their employees based upon the behaviors that they exhibit, the programs and policies they carry out, and the way employees are treated on a daily basis. In so doing, organizations and their leaders demonstrate how employees are truly valued - separate and apart from what may be the proclaimed principles and priorities that mark a corporation's walls or annual report. Many organizations reduce or eliminate status barriers (Caldwell \& Floyd, 2014; Pfeffer, 1998) in their efforts to treat employees as partners rather than as subordinates. Engagement is enhanced in organizations when an organizational culture creates a sense of community or belonging among its employees (Graham, 2014).

Recognizing employee contributions and giving credit to those employees, providing profit sharing or gain sharing compensation systems, celebrating organization successes, and saying "Thank you" effectively and meaningfully also encourages a sense of organization commitment to employees and generates a sense of belonging and employee loyalty (Pfeffer, 1998). Organizations recognize that one of their most important tasks is to create strong connection 
with their employees, and that this connection or sense of belonging enhances employee commitment and a firm's ability to compete in the marketplace (Caldwell, et al., 2015). The empirical research about employee satisfaction confirms that organization identification and employee engagement are closely linked (Karanika-Murray, et al., 2015).

Building on this research about the nature of employee engagement and organizations that create a sense of belonging, we present our sixth proposition.

$\mathbf{P}_{6}$ : Organizations that consciously seek to create a sense of belonging by treating employees as partners in the business and building relationships of high loyalty to employees who help the organization succeed have higher levels of employee engagement and extra role behavior than organizations that do not seek to create that sense of belonging.

We note, as we indicated hereinabove, that organizations who recognize and adopt all of these six contributing factors to employee engagement create aligned human resource management systems and an organizational culture that involves top management, human resource staff, supervisors and managers, and other employees in the process of creating that culture. Moreover, the empirical evidence suggests that organizations that adopt all of these factors are much more likely to see direct benefits, as measured by greater employee involvement and ownership, than organizations which adopt individual factors on a piece-meal basis.

\section{Contributions of the Paper}

Employee engagement can enable organizations to substantially improve their long-term profitability picture and their competitive advantage by utilizing the knowledge, skills, abilities, and other capacities that are so often underutilized in the modern organization (Caldwell \& Hansen, 2010). The following are four contributions of this paper to the employee engagement literature.

1) We identify the importance of engagement as an employee behavior achieved by empowering employees and creating a high trust organizational culture. Engaged and empowered employees who are treated as valued organizational partners have been shown to consistently improve organizational productivity and profitability.

2) We explain six factors related to creating a culture of engagement and provide insights about the importance of each of these factors in strengthening employee commitment and ownership. Each of these factors implicitly involves the fact that employees are the key contributors to value creation in today's knowledge-, wisdom-, and information-based economy (Covey, 2004).

3) We frame employee engagement as a complex ethical relationship associated with the subjective nature of psychological contracts - the often unspoken and unwritten assumptions about duties owed that influence the degree to which employees perceive that they are fairly treated. Understanding the ethical and value-based assumptions of individual employees enables supervisors, managers, and organizations to strengthen their partnership with employees and optimize their commitment and creativity.

4) We offer six propositions about engagement that scholars and practitioners can reflect on, examine, and apply to determine their validity and practical contribution to organizational effectiveness. The propositions in this paper are eminently testable and provide opportunity for managers and supervisors to measurable improve employee commitment. They also provide a framework for academicians and scholars to test each proposition.

Although this paper is certainly not an exhaustive summary of the nuances of creating a culture of engagement, it nonetheless provides practical information and insights about the importance of increasing employee commitment by implementing an aligned human resource management system that treats employees with high regard.

\section{Conclusion}

As illustrated throughout this paper, abundant literature suggests that organizational dynamics are dramatically evolving, given the complexation of a more diverse and younger workforce. Strategic leaders must begin preparing their organizations for the inevitability of this labor market shift. Going forward, it is suggested that the next generation employees will be motivated to perform radically different from previous workforce generations. As workplaces become even more bounaryless, with the blurring of organizational structure, finding new and creative methods of ensuring employee engagement will bring new challenges to leaders. Creating a climate for success, sustaining customer service and promoting innovation will be harder for leaders to sustain, if they cannot effectively engage individuals in their work.

In order to conduct the appropriate and necessary analysis to appropriately diagnosis organizational performance through the prism of engagement, it is crucial to define and understand employee engagement and its varying 
components. From that, it is incumbent on organizations to establish a vision that creates and supports a culture of engagement. In doing so, it is important to deliver the appropriate messaging throughout the organization, but especially to first-level leaders. The focus of the organization's vision is supported by top organizational leaders promoting trust and openness at all levels. This may require a significant shift in leadership performance goals and practices. Appropriate HRD may be required to support those leaders needing assistance with the transition. Human Resource professionals may be uniquely positioned to support this effort and help establish systems to more fully support organization-wide employee engagement activities. This might also include developing new processes and systems to facilitate organizational acceptance. Lastly, organizational leaders must work diligently to create a culture for engagement. Without the support of an organization's top management and supervisors for creating an organization responsive to employee needs and desires, individuals may find it necessary to look elsewhere to meet their personal and professional career plans.

\section{References}

Adkins, A. (2015, January 28). Majority of U.S. employees not engaged despite gains in 2014: Gallop. Retrieved from http://www.gallup.com/poll/181289/majority-employees-not-engaged-despite-gains-2014.aspx

Akinlade, D. \& Shalack, R., (2016). Strategic human resource management in nonprofit organizations: A case for mission-driven human resource practices. Allied Academies International Conference: Proceedings of the Academy of Organizational Culture, Communications \& Conflict (AOCCC) 21(1), 1-5.

American Society for Quality. (2016). Continuous Improvement. Retrieved from http://asq.org/learn-about-quality/continuous-improvement/overview/overview.html

ASTD Research. (2013). 2013 state of the industry. Alexandria, VA: Association for Talent Development. Retrieved from https://www.td.org/Publications/Research-Reports/2013/2013-State-of-the-Industry

Ashar, M., Ghafoor, M., Munir, E., \& Hafeez, S. (2013). The impact of perceptions of training on employee commitment and turnover intention: Evidence from Pakistan. International Journal of Human Resource Studies, 3(1), 74-88. http://dx.doi.org/10.5296/ijhrs.v3i1.2924

Ashkenas, R. Ulrich, D., Jick, T. \& Kerr S. (2015). The boundaryless organization: Breaking the chains of organizational structure. San Francisco, CA: Jossey-Bass.

Beauchamp, T. (2008). The principle of beneficence in applied ethics, in Zalta, E.N. (Ed.), The Stanford Encyclopedia of Philosophy, Winter 2013 Edition, Stanford Business Press, Palo Alto, CA. Retrieved from http://plato.stanford.edu/archives/win2013/entries/principle-beneficence/

Bennis, W. \& Nanus, B. (2007). Leaders: Strategies for taking charge (Collins Business Essentials). New York, NY: Harper Business Essentials.

Block, P. (2013). Stewardship: Choosing service over self-interest. San Francisco, CA: Berrett-Koehler Publishers.

Block, P. \& Piersanti, S. (2013). Stewardship: Choosing service over self-interest. Oakland, CA: Berrett-Koehler Publishers.

Bowers, D. G., \& Seashore, S. E.. (1966). Predicting organizational effectiveness with a four-factor theory of leadership. Administrative Science Quarterly, 11(2), 238-263. http://doi.org/10.2307/2391247

Brower, H. H., Schoorman, F. D. \& Tan, H. H. (2000). A model of relational leadership: The integration of trust and leader-member exchange. The Leadership Quarterly, 11(2), 227-250. http://dx.doi.org/10.1016/S1048-9843(00)00040-0

Brown, M. T. (2005). Corporate integrity: Rethinking organizational ethics and leadership. Cambridge, NY: Cambridge University Press. http://dx.doi.org/10.1017/CBO9780511753718

Buber, M. (2011). I and thou. Eastford, CT: Martino Publishing.

Buckingham, M. \& Coffman, C. (1999). First break all the rules: What the world's greatest managers do differently. New York, NY: Simon \& Schuster, Inc.

Burchell, M. \& Robin, J. (2011). The great workplace: How to build it, how to keep it, and why it matters. San Francisco, CA: Jossey-Bass.

Burke, W. W. \& Noumair, D. A. (2015) Organization development: A process of learning and changing. Upper Saddle River, NJ: Pearson Education, Inc.

Burns, J. M. (2010). Leadership: Harper perennial political classics. New York, NY: Harper Collins. 
Caldwell, C. \& Floyd, L. (2014). High performance work systems: building commitment to increase productivity. $\begin{array}{lllll}\text { Graziadio } & \text { Business } & \text { Review, } & \text { Retrieved } & \text { from }\end{array}$ http://www.goiam.org/images/articles/headquarters/departments/hpwo-partnerships/graziadio_business_review _pepperdineu.pdf.

Caldwell, C., Floyd, L. A., Taylor, J and Woodard, B. (2014). Beneficence as a source of competitive advantage. Journal of Management Development, 33(10), 1057-1069.

Caldwell, C. \& Hansen, M. H. (2010). Trustworthiness, governance, and wealth creation. Journal of Business Ethics, 97(2), 173-188.

Caldwell, C., Licona, B., \& Floyd, L. A. (2015). Internal marketing to achieve competitive advantage. International Business and Management, 10(1), 1-8.

Cherniss, C., Grimm, L. G., \& Liautaud, J. P. (2010). Process-designed training: A new approach for helping leaders develop emotional and social competence, Journal of Management Development, 29(5), 413 - 431. http://dx.doi.org/10.1108/02621711011039196

Christensen, C. M. (2012). How will you measure your life? New York, NY: Harper Collins Publishers.

Christensen, C. M. (2013). HBR's 10 must reads on innovation. New York, NY: Harvard Business Review.

Christensen, C. M. (2016). The innovator's dilemma: When new technologies cause great firms to fail. New York, NY: Harvard Business Review Press.

Colombo, E. \& Stanca, L. (2014). The impact of training on productivity: evidence from a panel of Italian firms. International Journal of Manpower, 35(8), 1140 - 1158. http://dx.doi.org/10.1108/IJM-08-2012-0121

Corporate Leadership Council. (2004). Driving performance and retention through employee engagement. Washington, DC: Corporate Executive Board.

Covey, S. R. (2004). The 8th habit: From effectiveness to greatness. New York, NY: Free Press.

Daneshgari, P. \& Moore, H. (2016) Organizational transformation through improved employee engagement - how to use effective methodologies to improve business productivity and expand market share. Strategic HR Review, 15(2), 57 - 64. http://dx.doi.org/10.1108/SHR-02-2016-0007

Davenport, T. H. (2013). Thinking for a living: how to get better performances and results from knowledge workers. New York, NY: Harvard Business Press.

Depree, M. (2004). Leadership is an art. New York, NY: Doubleday.

DeVaro, J. \& Morita, H. (2013). Internal promotion and external recruitment: A theoretical and empirical analysis. Journal of Labor Economics, 31(2), 227-269. http://dx.doi.org/10.1086/667814

Duckworth A. (2016). Grit: The power of passion and perseverance. New York, NY: Schribner.

Ellinger, A. D. (2012). Supportive supervisors and managerial coaching: Exploring their intersections. Journal of Occupational and Organizational Psychology, 86(3), 310-316. http://dx.doi.org/10.1111/joop.12021

Federman, B. (2009). Employee engagement: A roadmap for creating profits, optimizing performance, and increasing loyalty. San Francisco, CA: Jossey-Bass.

Freeman, R. E. (2010). Strategic management: A stakeholder approach. Cambridge, NY: Cambridge University Press. http://dx.doi.org/10.1017/CBO9781139192675

Fryer, K. J. Jiju, A., \& Alex, D. (2007). Critical success factors of continuous improvement in the public sector: A literature review and some key findings. Total Quality Management, 19(5), 497-517. http://dx.doi.org/10.1108/09544780710817900

Graham, A. (August 8, 2014). The 5 most important employee engagement needs. TD Magazine. Retrieved from https://www.td.org/Publications/Magazines/TD/TD-Archive/2014/08/Webex-5-Most-Important-Employee-Eng agement-Needs

Hart, D. W. \& Thompson, J. A. (2007). Untangling employee loyalty: A psychological contract perspective. Business Ethics Quarterly, 17, 297-323. http://dx.doi.org/10.5840/beq200717233

Hayes, L., Caldwell, C., Licona, B. \& Meyer, T. E. (2015). Follower behaviors and barriers to wealth creation. Journal of Management Development, 34 (3), 270-285. http://dx.doi.org/10.1108/JMD-09-2013-0111 
Hollenbeck, J. R., \& Jamieson, B. B. (2015). Human capital, social capital, and social network analysis: Implications for strategic human resource management. Academy of Management Perspectives, 29(3), 370-385. http://dx.doi.org/10.5465/amp.2014.0140

Hosmer, L. T. (2010). Ethics of management. Burr Ridge, IL: McGraw-Hill Education.

Huhtala, M., Tolvanen, A., Mauno, S. \& Feldt, T. (2015). The associations between ethical organizational culture, burnout, and engagement: A multilevel study. Journal of Business \& Psychology, 30(2), 399-414. http://dx.doi.org/10.1007/s10869-014-9369-2

Johnson, J. L. \& O'Leary-Kelly, A. M. (2003), The effects of psychological contract breach and organizational cynicism: Not all social exchange violations are created equal. Journal of Organizational Behavior, 24, 627-647. http://dx.doi.org/10.1002/job.207

Karanika-Murray, M., Pontes, H.M., Griffiths, M.D. \& Biron, C. (2015). Sickness presenteeism determines job satisfaction via affective-motivational states. Social Science and Medicine, 139, 100-106. http://dx.doi.org/10.1016/j.socscimed.2015.06.035

Ketter, P. (January 3, 2008). The big deal about employee engagement. TD Magazine. Retrieved from https://www.td.org/Publications/Magazines/TD/TD-Archive/2008/01/The-Big-Deal-About-Employee-Engagem ent

Kickul, J. (2001). Promises made, promises broken: An exploration of employee attraction and retention practices in small business. Journal of Small Business Management, 39(4), 320-335. http://dx.doi.org/10.1111/0447-2778.00029

Kilroy, J. \& Dundon, T. (2015). The multiple faces of front line managers: A preliminary examination of FLM styles and reciprocated employee outcomes. Employee Relations, $37(4), 410 \quad-\quad 427$. http://dx.doi.org/10.1108/ER-06-2014-0071

Kivland, C. (2016). Corporate study: 2014-2015 -- Will an increase in the emotional and social competence (ESC) scores of leaders directly correlate to higher engagement of their direct reports? In N. M. Ashkanasy, W. J. Zerbe, \& C. E.J. Hartel Editors (Eds). Research on Emotion in Organizations, 12th edition. Bingley, UK: Emerald Group Publishing.

Kivland, C. \& King, N. (2014). Six reasons why leadership training fails: A research review. Chicago, IL: The Liautaud Institute

Kouzes, J. M. \& Posner, B. Z. (2012). The leadership challenge: How to make extraordinary things happen in organizations. San Francisco, CA: Jossey-Bass.

Lipman, V. (2015). The type B manager: Leading successfully in a type A world. Upper Saddle River, NJ: Prentice Hall Press.

Lockwood, N. R. (2007). Leveraging employee engagement for competitive advantage: HR's strategic role. SHRM Research Quarterly, 1, 1-12.

Loehr, J. \&Schwartz, T. (2005) The power of full engagement: Managing energy, not time, is the key to high performance and personal renewal. New York, NY: Free Press.

Luthans F., Youssef, C.M., \& Avolio, B. J. (2007). Psychological capital. New York, NY: Oxford University Press.

Macey, W. H. \& Schneider, B. (2008), The meaning of employee engagement. Industrial and Organizational Psychology, 1 (1), 3-30. http://dx.doi.org/10.1111/j.1754-9434.2007.0002.x

Manion, J. J. (2012). The workforce engagement equation: A practitioner's guide to creating and sustaining high performance. Boca Raton, FL: CRC Press.

Manroop, L., Singh, P., \& Ezzedeen, S. (2014). Human resources systems and ethical climates: A resource-based perspective. Human Resource Management, 53(5), 795-816. http://dx.doi.org/10.1002/hrm.21593

Meere, M. (2005). High cost of disengaged employees. Employee Engagement Industry Briefing. Victoria, AU: Swinburne University of Technology.

Northouse, P. G. (2015). Leadership: Theory and practice. Los Angeles, CA: Sage Publications, Inc.

Paine, L. S. (December, 2003). The fiduciary relationship: A legal perspective. Harvard Business School Background Note, 304-064. (Revised November 2015.) 
Organ, D. W., Podsakoff, P. M., \& MacKenzie, S. B. (2005). Organizational citizenship behavior: Its nature, antecedents, and consequences. Los Angeles, CA: Sage Publications, Inc.

Pangarkar, N. (2011). High performance work teams: Successful strategies from the world's top achievers. San Francisco, CA: Jossey-Bass.

Perrini, F., Russo, A., Tencati, A. \& Vurro, C. (2011). Deconstructing the relationship between corporate social and financial performance. Journal of Business Ethics, 102, 59-76. http://dx.doi.org/10.1007/s10551-011-1194-1

Peshawaria, R. (2013, September 22). Trust: The currency of leadership. Forbes/Leadership. Retrieved from http://www.forbes.com/sites/rajeevpeshawaria/2013/09/22/trust-the-currency-of-leadership/\#c23037e24f5c

Pfeffer, J. (1998). The human equation: Building profits by putting people first. Boston, MA: Harvard Business School Press.

Pfeffer, J., \& Sutton, R. I. (2013). The knowing-doing gap: How smart companies turn knowledge into action. Boston, MA: Harvard Business Press.

Rath, T. \& Clifton, D. O. (2004). How full is your bucket? New York, NY: Gallop Press.

Robbins, S., De Cenzo, D. Coulter, M. \& Woods, M. (2013). Management: The essentials. Frenchs Forest, AU: Pearson Australia.

Robinson, S. L. \& Rousseau, D. M. (1994). Violating the psychological contract: Not the exception but the norm. Journal of Organizational Behavior, 15(3), 245-259. doi: 10.1002/job.4030150306

Rothwell, W, J. (2014). Creating engaged employees: It's worth the investment. Alexandria, VA: Association for Talent Development.

Rousseau, D. M. (1995). Psychological contracts in organizations: Understanding written and unwritten agreements. Los Angeles, CA: Sage Publications, Inc.

Saks, A. M. (2006). Antecedents and consequences of employee engagement. Journal of Managerial Psychology, 21(2), 600 - 619. http://dx.doi.org/10.1108/02683940610690169

Schaufeli, W. B. \& Bakker, A. B. (2010). Defining and measuring work engagement: Bringing clarity to the concept. In A. B. Bakker \& M. P. Leiter (Eds), Work engagement: A handbook of essential theory and research (10-24). New York, NY: Psychology Press.

Schein, E. H. (2010). Organizational culture and leadership. San Francisco, CA: Jossey-Bass.

Senge, P. M. (2006). The fifth discipline: The art and practice of the learning organization. New York, NY: Doubleday.

Shuck, M. B. (2005). Employee Engagement: An Examination of Antecedent and Outcome Variables (Doctoral Dissertation). Retrieved from FIU Electronic Theses and Dissertations. Paper 235. http://digitalcommons.fiu.edu/etd/235

Sorenson, S. (2013, June 20). How employee engagement drives growth: Gallop. Retrieved from http://www.gallup.com/businessjournal/163130/employee-engagement-drives-growth.aspx

Taneja, S., Sewell, S. S., \& Odom, R. (2015). A culture of employee engagement: A strategic perspective for global managers. Journal of Business Strategy, 36(3), 46-56. http://dx.doi.org/10.1108/JBS-06-2014-0062

Thompson, J. A. \& Hart, D. W. (2006). Psychological contracts: A nano-level perspective on social contract theory. Journal of Business Ethics, 68(3), 229-241. http://dx.doi.org/10.1007/s10551-006-9012-x

Thor, S. (2013). MOOD righting. Quality Progress, 46(5), 34-40. Retrieved from http://search.proquest.com.tcsedsystem.idm.oclc.org/docview/1370892188?accountid=34120

Ulrich, D. \& Young, J. (2012). HR from the outside in: Six competencies for the future of human resources. Burr Ridge, IL: McGraw-Hill Education.

Wagner, R., \& Harter, J. K. (2006). 12: The great elements of managing. Washington, DC: The Gallup Organization.

Weinzimmer, L., Robin, J., \& Michel, E. (2012). The measurement of strategic orientation and its efficacy in predicting financial performance. Journal of Business Strategies, 29(2), 81-98.

Zeidern, D., Matthews, G., \& Roberts, R. D. (2009). What we know about emotional intelligence: How it effects learning, work, relationships, and our mental health. Cambridge, MA: MIT Press. 